\title{
The strategic narration of future identity during times of crises: evidence from the European Commission
}

\author{
PAULINE HEINRICHS \\ Royal Holloway, University of London, UK \\ pauline.heinrichs.2011@live.rhul.ac.uk
}

\begin{abstract}
What kind of Europe the EU seeks to be, how it perceives itself and how it seeks to enact this Europe is a highly contentious issue and has powerful political stakes attached to its construction and realisation. This paper is specifically interested in how crises can constitute a compounded and expanded space for agency of political actors to forge identity narratives of the future. This paper draws on speeches by EC officials from 16 July 2019 to 7 July 2020, while coding along four analytical markers for crises as identified by Filip Ejdus (2020, p. 2, italics in original): "existence, finitude, relations and autobiography". This article finds that while actors seek to create space for political agency by writing a moment of existential (external) crises to the EU's project, they appear less equipped to use this moment politically. In this way, they co-construct a space potentially open to political creativity, but fail to fill this space with political creativity as to the future of the autobiographical narrative.
\end{abstract}

Key words: ontological security, crisis, strategic narratives, temporality, uncertainty, European Union

\section{Introduction}

The introduction to many of the recent academic publications on the European Union (EU) begin with listing the manifold crises that the EU has faced in recent years. There is a substantial list to draw from: the Eurozone Crisis, Brexit, the surge of populism, the refugee crisis, the ongoing conflict in Ukraine, and multiple terrorist attacks. Yet, many of the speeches of the last Commission President Jean-Claude Juncker (European Commission, 2019d, italics added) also noted that the EU had prevailed and emerged stronger in the process of overcoming these crises:

While strengthening our economy, we have also strengthened our resilience. This I can tell you, because we have been tried and tested, again and again ... But each time we have shown solidarity when it counted the most, unity when disunity threatened to prevail, and true European resilience.

The optimistic stance on a reinforced strength of the EU appeared to mark a move forward in a spirit of recovery - then the deadly global pandemic Covid-19 shut down the world economy and forced countries around the world into unprecedented lockdowns. Crisis has struck again and more profoundly than could have been foreseen by any of the optimistic stances taken by Juncker at the end of his Presidency. To be sure, many of the long-term ramifications are to be determined and examined in the future. However, the examination 
of crisis narratives at the onset of the new EU Commission (EC) provide an excellent opportunity to analyse the argument made in this paper in 'real time'.

What kind of Europe the EU seeks to be, how it perceives itself and how it seeks to enact this Europe, is a highly contentious issue and has powerful political stakes attached to its construction and realisation. In this way, not only "memories about Europe are contested" (Pakier \& Stråth, 2010, p. 2) but so are the proposals and visions that seek to guide the identity commitments of the future, especially when negotiated during moments that are unanimously recognised as crises (Heinrichs, 2020).

In expanding on the scholarship in ontological security, this study seeks to examine how it can better incorporate agency in making sense of unravelling crises and how the construction of crises can have effects on how strategic narratives can make sense of the world. In order to trace the construction of narratives of future identity commitments, this article draws on speeches by EC officials from July 16, 2019 to July 7, 2020. July 16, 2019 marked the election of the new EC president Ursula von der Leyen and thus constitutes the moment from which new frameworks and possible futures can be traced in particular. Speeches are coded along four analytical markers for crises as identified by Filip Ejdus (2020, p. 2, italics in original): "existence, finitude, relations and autobiography". The analytical marker of existence is characterised by a description of the current mode of existence. Through it, actors make sense of the current state of the Self, the world and system in which they are situated. Finitude describes the existential questions posed to the Self, rather than the immediate challenges or its mode of existence. The analytical marker of relations traces the type of relationships and the relevance of relationship for an understanding of the Self. The analytical marker of autobiography examines the different elements of the EU's autobiography and narrative of the Self. In tracing the analytical markers in all 191 speeches examined, I seek to find links to how actors portray agency and how they envision futures and tie it to narrations of crisis and identity. I trace the analytical markers by extracting phrases that dominantly characterise each analytical marker and summarise each speech in summary sheets to identify common themes of each analytical marker. I take the characteristic features of each marker - as reflected in what they seek to address - and highlight them in each summary sheet to operationalise and realise the theoretical model by allowing for comparative analysis across themes, without infringing upon the critical methodological commitment to "ongoing and evolving learning" (Schwartz-Shea and Yanow 2012, p. 55).

\section{Ontological security, identity narratives and agency}

What are identity narratives and how do they link to ontological security and agency? To start with, identity narratives can be considered ordering devices that causally link different elements of the story of the Self into a coherent structure. They link past, present and future alongside and through such a coherent structure. Through such a structure the Self can make sense of itself, but through it, others also make sense of the Self. Identity narratives do not have to center around state actors, they can be used by individuals, groups, organisations, states and supranational bodies, such as the EU. Identity narratives are "a set of ideas that are generally accepted by any group of actors as defining what their collectivity is and the general rules under which it operates" (Clunan, 2009, p. 28). Moreover, the collectively shared set of values, ideas and norms that guide and shape the collective's behaviour is not fixed and uncontested. A multiplicity of actors within an unfixed collectivity can come to question the structural conditions that guide normative 
codes of conduct. Likewise, external actors to a collective can come to question or actively target the integrity of that collective (see Bially-Mattern, 2005).

Alister Miskimmon, Ben O’Loughlin and Laura Roselle (2013, p. 32) have considered identity narratives as a "claim to attention or labelling". Whereas identity narratives are not necessarily strategically used, they serve to fulfil important and meaningful strategic objectives when they are. Similarly, when strategically used, identity narratives can become a powerful and sometimes detrimental tool to substantiate practices of exclusion. Collectives thus, become bound by and through narratives (Polletta, 1998). Identity narratives also serve an important function for collectives when they face uncertainty and to guide through crises.

The scholarship in ontological security has conceptualised crises and the anxiety around them as posing existential questions to the integrity of the Self (see Ejdus, 2020; Kinnvall, 2004; 2006; Steele, 2008, Mitzen, 2006a; 2006b; 2018). Further although mostly by focusing on identity narratives by states and the impact of crises on them, the burgeoning field has since adapted its approach to many different collectives, including the EU (Kinnvall, Manners \& Mitzen, 2018). While narratives and crises are central to the literature on ontological security, it has yet to link it to the study of strategic narratives, which is the theoretical innovation I suggest here. This is important because ontological security has made anxiety caused by crises a central aspect to understanding state behaviour. While it has paid particular attention to identity narratives as a means to smoothen out inconsistencies and provide reassurances in light of crises, it has yet to fully explore how such moments of crises can be moments to deploy and enable agency.

For the EU, the noteworthy link between crises and agency that I seek to advance here has been explored, among others, by Jennifer Mitzen (2018, p. 393), who argues that "while crises unleash anxiety, they do not necessarily portend the worst: because they disrupt old routines, crises can open space for new political possibilities." Further, the EU should "[a]s a self-consciously hybrid, 'post-national' political form ... would seem poised to take advantage" but "[i]nstead it is stuck". This paper expands on the argument in that it argues that the anxiety controlling mechanisms also have a spillover effect for how the future of the EU is narrated and subsequently enacted.

While crises have the potential to produce moments at which actors can seek to deploy agency, it is important to recognise how they do. The argument made here is that even when political actors seek to break out of routine practices, or seek to exert a political agency potentially inherent to moments of anxiety, the creativity surrounding the "embrace" (Berenskoetter, 2020, p. 288) of anxiety is crucially linked to how temporal claims are written into these moments of agency. Political creativity, then, is not merely a product of anxiety, but instead a strategy to overcome existential questions to the narrative of the Self. Much of this resonates closely with historical institutionalism (see Pierson, 2004; Pierson \& Skocpol, 2001; Sanders, 2006; Mahoney \& Thelen, 2009), which has long been side-lined in IR (Fioretos, 2011), but which substantially shares the "primacy it accords to temporality" (Fioretos, 2011, p. 371). However, my argument goes beyond the construction of path-dependent constraints of policy choices through critical events. It, instead, opens up historical processes to agency and beyond rationality-centric explanations of policy behaviour. In the next section, this article will explore the four different analytical markers according to which this research has examined the speeches. 


\section{Existence}

In the analysis of the speeches given by members of the EC, one pervasive theme of the mode of existence weaves through the sensemaking of the Self, namely that of crisis. In one of her first speeches as a candidate to become the next President of the EC, Ursula von der Leyen (European Commission, 2019a), for example, argues that "the whole world is being challenged by disruptive developments that have not passed Europe". While the current mode of existence is characterised by crisis, it is noteworthy to examine the subject-positioning of Europe in narrating the current mode of existence. Time and again, different actors position the EU as subject to a world in crisis, and within a system that is challenged by disruptions to its usual functioning order. In this way, the system narrative organises the EU as part of a system in crises, by which it is subsequently affected.

Whereas crisis is the narrated mode of existence of the EU within a system, it is juxtaposed to action and dynamics to tackle crises through policy narratives. The EU is positioned as both subject to crises and as able to develop behavioural tools to approach and manage crises effectively. In this process, Ursula von der Leyen, President of the EC, argues that the EU is "not optimistic, ... not pessimistic", but "determined" (European Commission, 2020f). Likewise, Vice-President Maroš Šefčovič (European Commission, 2020d) argues that, the EC "plan[s] to table 93 major initiatives grouped under 43 policy objectives or packages. In all cases, these are defining initiatives for this entire decade and in some cases, for the first half of this century." Even more vividly, Executive Vice President Frans Timmermanns (European Commission, 2020c) argued at the Conference on the first European Climate Law on January 28, 2020: "You can't drown your problems in alcohol. And you can't drown these problems by denying them. They will come back even stronger”.

In the mode of existence guided by crisis, members of the EC thus see agency as necessity, or else these crises will consume Europe and eventually, the international order. In examining the narration of agency through policy proposals, it is noteworthy that agency is closely linked to managing the future by policy choices in the present. In this way, actors of the EC build a narrative of progressiveness through their policy proposals as a means to countering the crises of the present, but also the future, which more generally loom large on the horizon. However, actors reflect on their agency by linking innovation and competitiveness of the EU in the future and thus seek to enable the EU's future potential.

\section{Finitude}

The first finding, here, is that the analytical marker of the mode of existence and of finitude are difficult to disentangle or place in different categories. The current mode of existence is closely narrated through finitude and I suggest that they are difficult to disentangle because the theme of (existential) crises is so pervasively narrated. As Ejdus (2017, p. 11) notes: "While the previous question was about the awareness of the self and of external reality, this one is about agents' awareness of their own finitude and the fear of the unknown that death brings". How do actors narrate questions that concern the finitude of life and politics? What is the purpose in the indeterminacy of and behind death? EC members talk about the existing crises in a way that suggests the international order is falling apart. They simultaneously narrate the existentialism of specific crises, such as the climate crisis, or Covid-19 and the health crisis as a means to define the momentous rupture or break at which they can reposition themselves and their actions. Actors seek to position the EU as central to defining purpose. "They say a strong soul shines bright after 
every storm. If we all stand up for Europe today - with courage trust and solidarity - I know that tomorrow Europe's soul will shine brighter than ever before" (European Commission, 2020h), von der Leyen states. The existentialism of the crises is juxtaposed to the ephemeral nature of the EU provided the right decisions are made and the EU is future-proof. Only, however, if at this 'critical juncture' the right decisions are made: "We are standing at a fork in the road: will this virus permanently divide us ... or will we become a strong continent?”. (European Commission, 2020g). According to von der Leyen (European Commission, 2020h), it is "this Union of ours that will get us through"; that is the European Union is the central answer to the indeterminacy of the finitude of politics. The analytical marker of finitude is thus used to narrate temporality, notwithstanding the severity of either the climate or the health crisis. Von der Leyen thus positions the EU as crucial to overcome these crises and the EU is indispensable in the face of uncertainty.

\section{Relationships}

The analytical marker of relations discusses three dominant themes. The future relationship among citizens and between citizens and the EU; the future relationship with the United Kingdom (UK) after Brexit; the future geopolitical relationship in relation to trade and more generally with new or established partners, such as Japan but also Russia and the United States. The negotiation of the future relationship with the UK illustrates the theoretical proposition made in this paper particularly well. First, the re-negotiation of the future with the UK is frequently used as a means to underline and emphasise the future viability of the European project. Whereas President Juncker and Ursula von der Leyen do not differ in content, they do differ in their approach to crafting narratives as tied to the future: "As the European Union moves forward," Juncker says, "we must also deal with the departure of a Member State" (European Commission, 2019c). Similarly, he says that "the other key subject at this stage is our common ambition for our future relationship and for our strategic partnership which me must build, or rebuild, with the United Kingdom after Brexit” (European Commission, 2019c). Ursula von der Leyen writes a more active break, followed by "new beginnings". She repeatedly tells the story of Brexit as one of "old friends and new beginnings" (European Commission, 2020a; 2020e). She elaborates (European Commission, 2020a): "We want to stay good friends, good neighbours and partners." Writing the story of "new beginnings", as "old friends" is a particularly instructive way of writing and narrating the future relationship. Through the conceptual metaphor of "old friends and new beginnings," von der Leyen writes break and continuity simultaneously. In this duality, she narratively moves structures, while keeping the subjects temporally separate from the structure. Simply put, "old friends", bound by the past and through "shared values", move differently to "new beginnings", or the structure of new beginnings. Through the duality, von der Leyen is able to write Brexit as a rupture, while maintaining the strength of the EU and its internal coherency because the rupture is structural and not necessarily impinging upon the integrity of the EU.

One additional narrative around the analytical marker of relationships is crucial: that of the relationship between generations. Much of the narrative on intergenerational responsibility also links closely to the attempts to write the autobiographical narrative of the EU. In promoting the Covid-19 recovery programme Next Generation EU - a name that highlights the importance of the generational contract - Ursula von der Leyen (European Commission, 2020j) states "Next Generation EU is an alliance between generations. We, the EU, are for the first time borrowing money from our children. So our investment today must deliver for our children". Likewise, Barnier (European Commission, 2020b) states: "We did not create the European Union. We inherited it from 
our parents and grandparents. It has brought us peace, opportunities, regional development and a better understanding of each other", thereby invoking a story about how the EU came to be and its responsibility to take care of the legacy of previous generations. He goes further and shifts to the future in saying: "It is now our responsibility to take this project forward, to improve it, to change it, where necessary, and to equip it for the next generations" (European Commission, 2020b).

\section{Autobiography}

While members of the EC seek to narrate the foundational moment for the future viability, relevance and importance of the EU, they fail to comprehensively identify the identity narrative that is supposed to fill this future, apart from the commitment to a "climateneutral, digital and social" (European Commission, 2020i) Europe. To be sure these are essential characteristics, concepts and directions, but they are not fully embedded in an identity narrative that makes sense of the future envisioned. In fact, their appeal and inclusiveness could be strengthened through a coherent identity narrative, as they indicate purpose and direction, not, however order and means for identification. Strikingly, the autobiographic narrative is relatively stable up to the breaking point narrated through the crisis. However, from the moment at which the mode of existence is established as a moment of crisis, the coherency of the autobiographical narrative falls short in developing into a comprehensive and cohesive narrative. President Ursula von der Leyen (European Commission, 2020i) argues, for example, that "Europe is a story about generations and each generation of Europeans has its story". She further elaborates:

For our Union's founding generation, the story was about building a lasting peace where there was only suffering, pain and destruction.

For the generation that followed, it was about pursuing prosperity and freedom by choosing the unity of our single market and our single currency.

Our next story was about reuniting our European family by bringing our brothers and sisters back in from the cold and welcoming them home - to the heart of our Union.

However, when tasked with creating an emerging narrative for the next generation, she withdraws into narrating the mode of crisis instead:

Today, we face our very own defining moment.

What started with a virus so small your eyes cannot see it, has become an economic crisis so big that you simply cannot miss it.

Our unique model built over 70 years is being challenged like never before in our lifetime or in our Union's history.

The common European goods we have built together are being damaged.

Things we take for granted are being questioned ... This is Europe's moment.

(European Commission, 2020i) 
While she offers to "pave a strong path for our people and for the next generation" and argues that "Europe is in a unique position to be able to invest in a collective recovery and a common future", she falls short of offering a comprehensive narrative of that future, other than that the Union will be "climate-neutral, digital, social and a strong global player" (European Commission, 2020i.). The characteristic features are ambitious policy visions, but they fall short of narrating this vision through an identity narrative. I suggest here that this, then, results in the same difficulty the EU has faced in the recent decade, namely that of offering a coherent identity narrative for its future. When addressing the mode of existence with policies and policy narratives and for these policy narratives to make sense, they should align with identity and system narratives (see Miskimmon, O'Loughlin \& Roselle 2013). However, when the system narrative of crises is juxtaposed to policy narratives, without an accompanying identity narrative, it is difficult to create a compelling narrative that envisions the future identity of the EU.

From the perspective of identity narrative sensemaking in the future, the lack of autobiographical sensemaking is significant. Where autobiographical narratives occur, they are often deeply rooted in the historical emergence of the European project, not, however, in its future. Where the narration of a future autobiography links to the EU's history, four central themes emerge: unity, solidarity, strength, significance. Instead, future takes place narratively, not in this autobiographical marker, but in suggestions for policies by talking about (unidentifiable and likely narratively incomprehensible) sums of investment, the modes of existence, discussions of finitude and relationships.

\section{Conclusion}

The moment at which futures are narratively forged, are, such is the contention of this paper, best observed at moments recognised as crises by political and other actors. Crucially, the anxiety surrounding crises, opens the possibility of a narration of agency in the process of constructing the future. How political actors choose to write futures is not an organic, pre-defined path. Irrespective of whether these futures can be realised, the narration of futures can open and reshape scope for action and policy options, so that these futures can be enacted. Brent Steele (2017, p. 112) argues this point: "There is an internal vulnerability arising from aesthetic power, which comes from the need to see it in action", which in turn "leads to pockets of vulnerability, which arise because power, which had been operating 'in the dark', becomes revealed in decisive action”. While Steele (2017, p. 112) acknowledges that "such aesthetic insecurity holds the keys towards a re-formation of the Self", it is important to add that such reformation can only be realised through compelling strategic narratives of the future that are subsequently enacted. Should a narrative of the future lack compelling purchase, it is difficult to overcome the "pockets of vulnerability" (2017, p. 112) in action.

The introduction of this special issue reflected on Miskimmon (2017, p. 85) in concurring that the "hybrid nature of the institution ... frustrates efforts to speak with a single European voice in international affairs". However, in addition to that, while a successful use of agency around the moment(s) of pervasive crises might be difficult to assess while they are ongoing, actors require a more careful consideration as to how driving forward crisis narratives impacts writing future identity narratives. Note, for example, Benjamin Moffit's (2016) discussion on populist narratives. Crises and its narration can be a very powerful means for seeking legitimacy or pushing for certain policies. However, they might not be the most helpful tool in declaring an emboldened, "embrace" (Berenskoetter, 2020, p. 288) of anxiety towards a new future. 
In examining the four analytical markers, I have argued that while crises can constitute a moment to deploy political agency, strategic narratives that seek to overcome the crisis mode, need to offer more compelling alternatives to how the future is envisaged. However, if the mode of existence is too overwhelmingly argued as a crisis but not made sense through identity but policy narratives, it becomes difficult for actors to use this moment as a moment at which "creative-constitutive agency" (Berenskoetter, 2020, p. 282) can be deployed.

While the new EC seeks to offer a convincing identity narrative for the future, it appears to fail to forge a strategic narrative that can make sense of uncertainty through identity narratives. Considering the different functions of strategic narratives examined in particular in this Special Issue (see Introduction), it is noteworthy that each function appears to be undermined by lack of alignment with identity, system or issue narratives. Pragmatic narratives, appear to fully embrace that a 'new pragmatism' could be a means to establish a new European identity - irrespective of whether actors seek to pursue such a narrative. However, by focusing on policy responses alone, a pragmatic narrative can neither fully substantiate its functionality, nor can it provide a coherent means of identification. Likewise, an alternative narrative is compelling because it can, in theory, propose an alternative, rather than merely attesting the need for an alternative (as pervasively narrated through the analytical markers of existence and finitude). The reluctant narrative may be the most suitable function to describe the result of shortcomings in narrative alignment yet is neither a useful narrative to counter the pervasive sense of crisis, nor is it a means to negotiate identity narratives amidst claims for an emboldened vision for Europe's future. Nuanced narratives are visible only in so far as they serve the function to underline the uncertainty surrounding the crisis. However, in the sensemaking of the crisis, EC members fall short in using the functionality of nuance to provide a more nuanced understanding of European identity beyond its history. Lastly, the generational narratives are an important feature in seeking to legitimise certain behaviours, and in seeking to provide a basis for participatory interpretation with EU identity. They could be a crucial means forward, to make comprehensive sense of an EU identity feasible to internal and external audiences. Crafting an EU identity narrative that incorporates flexibility into times of unprecedented transition, might therefore, be a way forward for the EU's identity narrative impasse. If the EU's future identity narrative can grasp such movement, it could unlock the very creative "embrace" (Berenskoetter, 2020, p. 288) of uncertainty that times of crises require.

\section{References}

Berenskoetter, F. (2020). 'Anxiety, time, and agency.' International Theory, 12(2), 273290.

Bially-Mattern, J. (2005). Ordering International Politics: Identity, Crisis and Representational Force. New York and Oxon: Routledge.

Clunan, A.L. (2009). The Social Construction of Russia's Resurgence. Aspirations, Identity, and Security Interests. Baltimore: The Johns Hopkins University Press.

Ejdus, F. (2020). Ontological Insecurity. Serbia's Anxiety over Kosovo’s Secession. Cham: Palgrave Macmillan. 
European Commission (2019a, July 16). Opening Statement in the European Parliament Plenary Session by Ursula von der Leyen, Candidate for President of the European Commission [Press statement].

https://ec.europa.eu/commission/presscorner/detail/en/SPEECH_19_4230

European Commission (2019b, September 18). Discours du Président Juncker et du Négociateur en chef de la Commission européenne Barnier sur le retrait du Royaume-Uni de l'Union européenne lors de la session plénière du Parlement européen [Press statement].

https://ec.europa.eu/commission/presscorner/detail/fr/SPEECH_19_5610.

European Commission (2019c, October 9). Discours par le Président Juncker en plénière du Parlement européen à l'occasion du débat sur les préparations du Conseil européen des 17-18 octobre 2019 [Press statement].

https://ec.europa.eu/commission/presscorner/api/integration/rapid2/pressrelease_SPEECH-19-6059_fr.htm.

European Commission (2019d, October 19). Speech by President Juncker at the European Policy Centre Thought Leadership Forum [Press statement]. https://ec.europa.eu/commission/presscorner/detail/en/SPEECH_19_6163.

European Commission (2020a, January 10). Remarks by President von der Leyen at the joint press conference with Andrej Plenković, Prime Minister of Croatia [Press statement].

https://ec.europa.eu/commission/presscorner/detail/en/speech_20_21.

European Commission (2020b, January 27). Speech by Michel Barnier at the William J. Clinton Leadership Institute [Press statement].

https://ec.europa.eu/commission/presscorner/detail/en/speech_20_133.

European Commission (2020c, January 28). Executive Vice President Timmermans' remarks at the Conference on the first European Climate Law [Press statement]. https://ec.europa.eu/commission/presscorner/detail/en/SPEECH_20_144.

European Commission (2020d, January 29). Remarks by Vice-President Maroš Šefčovič at the College Read-Out: Commission Work Programme for 2020 [Press statement]. https://ec.europa.eu/commission/presscorner/detail/en/SPEECH_20_147.

European Commission (2020e, January 29). Speech by President von der Leyen in the Plenary of the European Parliament at the debate on the Withdrawal Agreement [Press statement]. https://ec.europa.eu/commission/presscorner/detail/en/SPEECH_20_140.

European Commission (2020f, January 31). Joint press statement by President von der Leyen with President Sassoli and President Michel on the withdrawal of the United Kingdom from the European Union [Press statement]. https://ec.europa.eu/commission/presscorner/detail/en/speech_20_169.

European Commission (2020g, March 26). Speech by President von der Leyen at the European Parliament Plenary on the European coordinated response to the COVID-19 outbreak [Press statement]. https://ec.europa.eu/commission/presscorner/detail/en/SPEECH_20_532. 
European Commission (2020h, April 16). Speech by President von der Leyen at the European Parliament Plenary on the EU coordinated action to combat the coronavirus pandemic and its consequences [Press statement]. https://ec.europa.eu/commission/presscorner/detail/en/speech_20_675.

European Commission (2020i, May 27). Speech by President von der Leyen at the European Parliament Plenary on the EU Recovery package [Press statement]. https://ec.europa.eu/commission/presscorner/detail/en/speech_20_941.

European Commission (2020j, June 13). Speech by President von der Leyen at the event 'Progettiamo il Rilancio', hosted by Giuseppe Conte, Prime Minister of Italy [Press statement]. https://ec.europa.eu/commission/presscorner/detail/en/SPEECH_20_1060.

Fioretos, O. (2011). Historical Institutionalism in International Relations. International Organization, 65(2), 367-399.

Kinnvall, C. (2004). Globalization and Religious Nationalism: Self, Identity, and the Search for Ontological Security. Political Psychology, 25(5), 741-767.

Kinnvall, C. (2006). Globalization and Religious Nationalism in India: The Search for Ontological Security. New York: Routledge.

Kinnvall, C., Manners, I., \& Mitzen, J. (2018). 'Introduction to 2018 Special Issue of European Security: Ontological (In)security in the European Union.' European Security, 27(3), 249-265.

Mahoney, J. \& Thelen, K. (2009). Explaining Institutional Change: Ambiguity, Agency, and Power. New York: Cambridge University Press.

Miskimmon, A. (2017). Finding a Unified Voice? The European Union through a Strategic Narrative Lens. In A. Miskimmon, B. O’Loughlin \& L. Roselle (Eds.). Forging the World. Strategic Narratives and International Relations. Ann Arbor: University of Michigan Press, 85-109.

Miskimmon, A., O’Loughlin, B. \& Roselle, L. (Eds.) (2013). Strategic Narratives: Communication Power and the New World Order. New York: Routledge.

Mitzen, J. (2006a). Ontological Security in World Politics: State Identity and the Security Dilemma. European Journal of International Relations, 12(6), 341-370.

Mitzen, J. (2006b). Anchoring Europe's Civilizing Identity: Habits, Capabilities and Ontological Security. Journal of European Public Policy, 13(2), 270-285.

Mitzen, J. (2018) Anxious community: EU as (in)security community. European Security, 27(3), 393-413.

Moffitt, B. (2016). The Global Rise of Populism: Performance, Political Style, and Representation. California: Stanford University Press.

Pakier, M. \& Strath, B. (Eds.). (2010), A European Memory? Contested histories and Politics of Remembrance, New York/Oxford: Berghahn Books.

Piersion, P. (2004). Politics in Time: History, Institutions, and Social Analysis. Princeton, N.J.: Princeton University Press. 
Pierson, P. \& Skocpol, T. (2001). Historical Institutionalism in Contemporary Political Science. In I. Katznelson \& H.V. Milner (Eds.). Political Science: State of the Discipline. New York: Norton, 693-721.

Polletta, F. (1998). Contending Stories. Narrative in Social Movements. Qualitative Sociology, 21, 419-446.

Sanders, E. (2006). Historical Institutionalism. In R.A.W. Rhodes, S.A. Binder \& B.A. Rockman (Eds.). The Oxford Handbook of Political Institutions. New York: Oxford University Press, (pp. 39-55).

Schwartz-Shea, P. \& Yanow, D. (2012). Interpretative Research Design. Concepts and Processes. New York: Routledge.

Steele, B. (2017). Aesthetics, Power, and Insecurity. Self-Interrogative Imaging and the West. In B. Herborth and G. Hellmann (Eds.). Uses of the West: Security and the Politics of Order. Cambridge: Cambridge University Press, (pp. 111-135).

Steele, B.J. (2008). Ontological Security in International Relations: Self-Identity and the IR State. London: Routledge. 